\title{
APROPRIAÇÃO E USO DOS ESPAÇOS DE LAZER DA POPULAÇÃO CURRAISNOVENSE
}

\author{
Recebido em: 11/04/2013
}

Aceito em: 02/03/2014

\author{
Renata Laís Ferreira de Santana ${ }^{1}$ \\ Josemery de Araújo Alves ${ }^{2}$ \\ Universidade Federal do Rio Grande do Norte (UFRN) \\ Currais Novos - RN - Brasil
}

RESUMO: O lazer hoje é considerado um direito do cidadão brasileiro regulamentado pela Constituição de 1988, e o poder público buscando satisfazer as necessidades da população e em conformidade com as leis federais, estaduais e municipais, constituem espaços públicos de lazer para o fomento dessa atividade. O presente artigo é resultado de uma pesquisa que teve como objetivo realizar um estudo com a população curraisnovense visando conhecer o processo de apropriação dos espaços públicos para o lazer da comunidade. Como metodologia foi utilizada uma amostragem não probabilística por conveniência, onde foram aplicados 160 formulários com a população curraisnovense para conhecer como é realizado o processo de apropriação dos espaços e identificar as necessidades da população frente aos espaços de lazer da cidade. Os principais resultados da pesquisa apontam que a população geralmente utiliza dos espaços públicos de lazer para confraternização com familiares e amigos, prática de esportes e lanches nos quiosques e espetinhos espalhados em todos os bairros da cidade. Foi constatado que os espaços públicos da cidade são passíveis para a apropriação e uso da população para o lazer, mas há uma carência de atividades que possam atrair esse público periodicamente.

PALAVRAS-CHAVE: Atividades de Lazer. Centros de Convivência e Lazer. Logradouros Públicos.

\section{APPROPRIATION AND USE OF SPACES FOR LEISURE POPULATION CURRAISNOVENSE}

ABSTRACT: The leisure today is considered a right of the citizen regulated by the Brazilian Constitution of 1988, and the government seeking to satisfy the needs of the population and in accordance with federal, state and local, as public spaces for leisure promoting this activity. This article is the result of a survey that aimed to conduct a study with curraisnovense

\footnotetext{
${ }^{1}$ Graduada em turismo/ UFRN(Ceres, Currais Novos, RN). Artigo proveniente do trabalho de conclusão de curso.

${ }^{2}$ Doutoranda em Recursos Naturais pela Universidade Federal de Campina Grande. Mestre em Turismo pela Universidade Federal do Rio Grande do Norte. Docente efetiva do Curso de Turismo da UFRN/Centro de Ensino Superior do Seridó. Pesquisadora do grupo de pesquisa do CNPq: "Gestão, Turismo e Políticas Públicas (GEPOLISTUR)".
} 
population in order to know the process of appropriation of public spaces for leisure community. The methodology we used a non-probability sample of convenience, where 160 forms were applied to the population curraisnovense to know how is done the process of appropriation of spaces and identify the needs of the population compared to the leisure facilities of the city. The main results of the research show that people often use public leisure spaces for socializing with family and friends, sports and snack kiosks scattered and skewered in all neighborhoods. It was found that the city's public spaces are subject to appropriation and use of the population for recreation, but there is a lack of activities that may attract this audience regularly.

KEYWORDS: Leisure Activities. Centers of Connivance and Leisure. Public Facilities.

\section{INTRODUÇÃO}

Apesar do lazer está presente na Constituição de 1988 como direito do cidadão, ainda existem barreiras no que diz respeito à prática do lazer nos espaços públicos oferecidos visando a satisfação das necessidades da população, bem como a busca pela melhoria da qualidade de vida dos munícipes.

A cidade de Currais Novos foi escolhida como objeto de estudo desta pesquisa pelo fato de conter diversas infraestruturas públicas que foram construídas como opção de lazer e socialização da comunidade, mas nem sempre são utilizadas adequadamente pela população. Diante dessa realidade, buscou-se abordar a temática do desenvolvimento do lazer nos espaços públicos para discutir e ter conhecimento de como é feita a apropriação desses espaços pela população.

Desse modo, o estudo apresenta relevância tendo em vista que se propõe ampliar as informações sobre o processo de apropriação e uso dos equipamentos e identificar as necessidades da população curraisnovense frente a oferta dos espaços de lazer da cidade, servindo de suporte para as ações das equipes envolvidas com o lazer, cultura e turismo.

Partindo desse pressuposto, o objetivo geral desta pesquisa, constitui-se em realizar um estudo com a população curraisnovense visando conhecer o processo de apropriação dos espaços para o lazer da comunidade. Para tanto, teve-se como objetivos específicos: 
- Verificar como ocorre a apropriação dos espaços e equipamentos de lazer;

- Catalogar os principais equipamentos e/ou atividades que a população gostaria que fossem oferecidas na cidade;

- Identificar os projetos e programas já oferecidos pelo poder público local propondo melhoria na sua programação;

- Identificar programas e projetos que são utilizados/implantados para a prática do lazer em espaços públicos de outras cidades do Brasil, servindo de exemplo para ações futuras;

Assim, a pesquisa traz significativas considerações sobre o reconhecimento das necessidades de valorização e uso dos espaços para o lazer, devido o levantamento das condições gerais de acessibilidade e utilização, identificando as necessidades de projetos sobre construção, adaptação e animação que visem a diminuição de barreiras que a população enfrenta para o uso desses espaços.

\section{METODOLOGIA}

Para atender aos objetivos, a metodologia aplicada é classificada como exploratória e descritiva, pois foi realizada pesquisa bibliográfica baseada em livros, monografias, artigos científicos, bancos de dados do Instituto Brasileiro de Geografia e Estatísticas (IBGE) e entrevistas informais com a população.

Para responder aos questionamentos levantados e relacioná-los ao referencial proposto, foram aplicados 160 formulários à população de Currais Novos para entender quando e de que forma são utilizados os espaços públicos para a prática do lazer, bem como quais atividades ou equipamentos a população gostaria que fossem oferecidos na cidade. Foi 
baseado em uma amostragem não-probabilística por conveniência onde os elementos são escolhidos de acordo com o interesse do pesquisador (DENKER, 2003).

Trata-se de um estudo com abordagem qualitativa e não foi estabelecido um número de formulários para cada bairro específico, a estratégia escolhida foi de acordo com a saturação de informações, uma vez visto que os dados estavam se repetindo a aplicação era suspensa. Ainda foi levado em consideração o tamanho de cada bairro e a quantidade de equipamentos de lazer dispostos, procurou-se uma proporção levando como base o número de questionários e extensão do bairro Centro, este foi o primeiro bairro a ser explorado para servir de norteador de quantidades de abordagens para as outras localidades.

A abordagem para a aplicação dos formulários foi realizada nas proximidades dos espaços de lazer e na UFRN de forma aleatória com as diversas faixas etárias, abordando quantidades expressivas para sanar os levantamentos de cada bairro da pesquisa.

O público contemplou 14 dos 15 bairros da cidade, entre os entrevistados não foi identificado nenhum habitante do Loteamento Santa Tereza. Por motivo de distância, tempo disponível para a pesquisa e pelo fato de o bairro se tratar de um loteamento ainda em constituição, não foi possível a aplicação com habitantes deste bairro, mas acredita-se que a pesquisa não perderá confiabilidade por este motivo.

\section{CONTEXTUALIZANDO O LAZER}

$\mathrm{Na}$ maioria das perspectivas apresentadas por autores renomados na área o conceito de lazer não é fácil de ser definido, é considerado por muitos como um fenômeno problemático e ambíguo, diante das diversas situações em que é proposto.

Marcellino (2006) apresenta em sua obra Estudos do Lazer: uma introdução, que não é possível entender o lazer de forma isolada, sem ter interações com as diversas esferas da vida social. O campo do lazer deve ter relação direta com as demais áreas de atividade do homem, não havendo essa consideração das demais áreas ou levando em conta apenas uma 
das atividades humanas, Marcellino (2006, p. 15) compara tal situação com a forma de conhecimento da humanidade é "como entender o homem de forma parcial", ou seja, não se chega a um conceito amplo, completo, ocasionando assim várias incógnitas na conceituação do tema.

Nessa relação, o autor mencionado também apresenta os aspectos fundamentais que devem ser considerados para a formulação e idealização da prática do lazer, tais como: as satisfações e "insatisfações, as pressões ou os processos de alienação que ocorrem em quaisquer dessas áreas” (2006, p.15).

Marcellino (2007, p. 10), conceitua lazer como "cultura vivenciada no tempo disponível das obrigações profissionais, escolares, familiares e sociais, combinando os aspectos tempo e atitude", visto como uma cultura não reduzida apenas às atividades artísticas, mas como uma gama de conteúdos culturais, pois o tempo para o lazer proporciona essa vivência de vários valores que interferem e contribuem para a formação e mudanças de ordem moral dos indivíduos da sociedade.

Os aspectos tempo e atitude citados acima, ajudam a caracterizar o momento de lazer. O "tempo" é relacionado ao espaço de tempo disponível para o lazer, fora das obrigações também citadas na conceituação de Marcellino (2007). E a "atitude" é caracterizada pelo tipo de relação entre o indivíduo e a experiência, ou seja, é a satisfação que a atividade provoca no indivíduo.

Esse aspecto atitude é bastante complexo, pois uma experiência realizada por um indivíduo pode proporciona-lo prazer e bem estar, que neste sentido é considerado como lazer, mas pode ser visto apenas como uma obrigação trabalhista como, por exemplo, cozinhar, muitos cozinham por prazer, sem nenhuma relação com obrigação, já outros, tem a cozinha como ambiente de trabalho, com total obrigações trabalhistas, descaracterizando como lazer. 
O lazer propicia uma socialização da comunidade fazendo com que os indivíduos, possam entrar em contato com diversos costumes, culturas, crenças e pensamentos.

O lazer é um conjunto de ocupações as quais o indivíduo pode entregar-se de livre vontade, seja para repousar, seja para divertir-se, recrear-se, entreter-se ou ainda para desenvolver sua informação ou formação desinteressada, sua participação social voluntária ou sua livre capacidade criadora após livrar-se ou desembaraçar-se das obrigações profissionais, familiares e sociais (DUMAZEDIER, 2004, p. 34).

O conceito de lazer apresentado por Jofre Dumazedier (2004), um dos autores pioneiros no assunto, retrata essa questão da socialização e contato com os diversos costumes e culturas, sendo considerado como uma forma "desinteressada" de absorção de conhecimento e informações, que em comparação ao conceito de Marcellino (2007) apresentado acima não difere muita coisa, apenas a presença e visão do lazer como cultura e não como componente presente na prática do lazer.

Outro fator importante encontrado na conceituação de Dumazedier (2004) é a relação do lazer com a satisfação das necessidades pessoais como o repouso, a diversão, recreação e entretenimento, sendo consideradas as principais funções do lazer.

Portanto, para a prática do lazer em suas diferentes dimensões, é necessário um planejamento e um local, um espaço para ser desenvolvido. Os espaços públicos urbanos são geralmente as únicas opções de espaços de lazer de uma determinada localidade.

\section{ESPAÇOS URBANOS: APROPRIAÇÃO E USO PARA FINS DO LAZER}

Os espaços públicos representam para a população, locais com funções culturais, sociais, ambientais, dentre outros, proporcionando sociabilidade e convivência entre os indivíduos. Exemplos destes espaços são praças, parques, ruas, praias, calçadas, quadras, quiosques e etc. Para Ribeiro (2008), os espaços públicos, mesmo sendo utilizados por toda população, diferem dos espaços coletivos no que diz respeito às restrições de grupos sociais:

Espaço público difere de espaço de uso coletivo. Embora muitos espaços sejam de uso coletivo, não são destinados a todos os grupos sociais, como exemplo temos os 
shoppings centers que embora o acesso seja livre, promove o encontro entre pessoas de uma determinada classe social, sendo incompatível com a ideia de espaço público, que é aberto e acessível a todos os grupos sociais. Ainda podemos citar o caso dos clubes ou grêmios recreativos associativos, que são destinados a um público específico (2008, p. 26 - 27).

No determinante espaço urbano, há três tipos de caracterização: o público, semipúblico e privado. O público são os espaços administrados pelo governo municipal, estadual ou federal e pertencente à população, onde a prefeitura é a responsável pela sua manutenção. Tais espaços são caracterizados pelo livre acesso da população, sua acessibilidade é totalmente gratuita e não diferenciam as diversas classes sociais na sua utilização, exemplos: as praças, quadras de esportes, praias, ruas, parques e outros. O semi-público é um espaço com algumas restrições no seu uso, como por exemplo, os quiosques, onde a acessibilidade é livre, mas que há uma cobrança na utilização do seu serviço. E o espaço privado é particular, pertencem a um proprietário onde é responsável pela administração e manutenção do espaço, restringe determinada camada da população para o uso, visto que é cobrado uma taxa para sua utilização, como por exemplo, os balneários, clubes, teatros, cinemas e outros (CARVALHO, 2012).

Ao colocar em prática as políticas de desenvolvimento determinadas pelos Planos Diretores, cria-se uma visão de duplo significado sobre os espaços públicos para a comunidade, ao mesmo tempo em que representa apenas infraestruturas relativas ao embelezamento e mercadorização das cidades, também é visto como um lugar para prática do lazer, partindo da relação trabalho/lazer, um lugar de referência da cultura e entretenimento proporcionando uma socialização da comunidade (FIGUEIREDO, 2008).

Nessa perspectiva, Silva (2012, p. 75) afirma que "os espaços não se restringe somente ao conjunto de formas materiais e a sua natureza legal, mas abarca ainda uma dimensão subjetiva, na esfera política e sociocultural”. 
É notável que a população já ver os espaços públicos como opção de referência para lazer, cultura e sociabilização dos indivíduos, mesmo estes não sendo específicos para a prática da atividade. Figueiredo (2008) complementa que, quando não há equipamentos específicos para esses fins, o poder público diante de um planejamento urbano utiliza de áreas com características diversas e adaptando-as para o lazer. Daí se configura a necessidade de refuncionalização dos espaços, implantando a eles novas funções e programas que possam proporcionar à população a prática do lazer. Em conformidade com Lopes (1999, p.1), os espaços públicos urbanos "devem essencialmente ser espaços de lazer, isto é, lugares de dinâmica cultural onde o lúdico faça ressaltar um conjunto de expressões ou rituais, sinônimos do direito à cidade e de usufruto de lugares agradáveis para viver”.

No planejamento desses espaços, já deveria ser pensado como um lugar que proporcionasse o bem estar da população com a vivência do lúdico como direito de todos e não só como uma infraestrutura de embelezamento da cidade para mostrar à população o "trabalho" do gestor, tendo como base a prática política recorrente.

As cidades do interior brasileiro especificamente, não contam com um número expressivo de espaços e equipamentos específicos de lazer, além de uma distribuição desigual entre os bairros (BAHIA et.al, 2008).

Essa distribuição desigual se configura na realidade de muitas cidades principalmente do interior, onde a concentração maior dos espaços, equipamentos e serviços de lazer é no centro da cidade. A necessidade do lazer é tão grande que em alguns bairros periféricos, a população cria lugares improvisados para sua recreação e lazer, como os bares e botequins nas esquinas dos bairros carentes.

O lazer nos espaços públicos não se reduz apenas como estratégia para atrair turistas e promover a cidade, embora o turismo também se alimente disto, trata-se de uma 
conquista, pois representa uma identidade do povo, das ações dos homens em que ali vivem (RIBEIRO, 2008).

A democratização do lazer está relacionada com a democratização dos espaços, uma vez constituído e divulgado, a apropriação destes pela população acontecerá e estará disponível para a prática do lazer.

Para Marcellino (2006), o lazer pode ser uma importante ferramenta no processo de valorização do patrimônio histórico cultural de uma cidade, além de preservar a identidade dos locais e aumentar o potencial turístico.

Ao comentar quando uma comunidade se apropria de um espaço público para o uso do lazer, por exemplo, é possível que haja uma mudança de comportamento do indivíduo em si, pois o lazer proporciona, como já mencionado anteriormente, uma interação maior com a própria população que traz consigo inúmeras culturas. Contexto confirmado por Marcellino (2007, p. 11) com uma de suas definições de lazer como sendo "um tempo privilegiado para a vivência de valores que contribuam para mudanças de ordem moral e cultural”.

Quando se questiona em lazer nos espaços públicos, logo se pensa nos elementos materiais que uma cidade disponibiliza, pois a prática do lazer proporciona uma dinâmica de todos os espaços urbanos, estes específicos ou não, como bibliotecas, escolas, praças, ruas, parques, bares, canteiros, centros de convivências, quadras de esportes, dentre outros.

Na questão do espaço ser ou não um lugar para a prática do lazer, há uma distinção na sua terminologia. Em uma cidade há espaços vistos como equipamentos específicos e não específicos para a prática do lazer, sendo estes também incluídos no quadro de classificação dos espaços no âmbito público, semi-público ou privado.

\subsection{EQUIPAMENTOS ESPECÍFICOS DE LAZER}


As cidades, ao longo do tempo, foram pensadas sob a ótica do trabalho, em que indústrias e fábricas surgiram numa proporção bem superior à dos espaços destinados para o lazer (TAVEIRA; GONÇALVES, 2012, p. 37). Mesmo nos dias atuais, o investimento em espaços de lazer ainda não é tão significante deixando a população com opções restritas.

Os equipamentos específicos são os espaços constituídos especificamente para a utilização da população na prática da atividade do lazer. Mesmo com a baixa quantidade de equipamentos específicos, a população ainda não utiliza dos espaços disponíveis constantemente por algum motivo, seja ele por questões financeiras, no caso dos espaços semi-públicos e privados, devido ao vandalismo e violência ou até mesmo, pelo espaço não estar sendo mais visto como um fato social, onde todos querem utilizar no mesmo espaço de tempo o equipamento, mas com a falta de programas de otimização desses espaços a população acaba "aposentando-os".

Bruhns (1997) apresenta as formas existentes dos equipamentos quanto à sua dimensão física de espaço e suas finalidades programáticas: os equipamentos especializados, polivalentes e turísticos.

- Equipamentos especializados ou microequipamento: são os equipamentos destinados a atender uma atividade específica ou um conteúdo cultural específico. Têm-se como exemplo as academias de ginásticas, teatros, centros esportivos, cinemas, bibliotecas e etc.

- Equipamentos polivalentes: podem ser classificados como equipamentos médios ou macroequipamentos. Os equipamentos médios polivalentes são destinados a receber uma programação diversificada, atendendo a vários interesses socioculturais, que comportam um número de 2.500 pessoas por dia e até 5000 em eventos nos fins de semana. Tem como exemplos: centros culturais, esportivos, comunitários e etc. E os Macroequipamentos são destinados ao 
atendimento de massa contemplando programação diversificada. Exemplos são os parques temáticos, reservas ecológicas, parques aquáticos, dentre outros.

- Equipamentos turísticos: todos aqueles destinados a atividade turística. Compreende uma diversificação de ofertas que possam atender as necessidades dos turistas. É composto por hotéis, acampamentos, pousadas, colônias de férias e etc.

Alguns desses equipamentos específicos, mesmo sendo espaços públicos de uma cidade, possuem intervenções da iniciativa privada, fato que proporciona alguns pontos positivos como: a manutenção do espaço, promoção de atividades específicas do lazer, como também alguns pontos negativos, podendo citar: a restrição de um público específico, devido a cobrança de taxas de manutenção.

Dumazedier (2008), em sua obra Sociologia empírica do lazer, apresenta diversos aspectos importantes sobre como deve ser compreendido o espaço de lazer. Um de seus pensamentos mais destacados por outros estudiosos do campo, é que "o espaço de lazer deve ser geograficamente implantado no local que melhor convém para cada caso particular" (2008, p. 170). A constituição de um espaço de lazer deve ser pensada estrategicamente, pois deve estar contido nas diversas escalas da área urbana principalmente contendo vias de acesso para a circulação da população, transporte e densidade de concentração da população.

Outro fator importante no seu pensamento em relação aos equipamentos específicos de lazer é a visão de segunda residência, com a extensão dos espaços para cada vez mais longe do centro da cidade, com finalidade de lazer nos finais de semana, férias ou até mesmo de residência principal, proporcionando o prazer dos indivíduos que se enquadram nas diversas áreas de interesses apresentadas anteriormente.

Diante dessa realidade, muitas vezes a solução não esta na construção de novos equipamentos, mas sim na revitalização e recuperação dos já existentes, com a melhoria na 
infraestrutura, promoção de atividades, programas e projetos para a otimização do seu uso. Em alguns casos, a alteração da função original é necessária caracterizando assim uma refuncionalização dos espaços, onde utilizam de equipamentos não específicos do lazer para a prática da atividade.

\subsection{EQUIPAMENTOS NÃO ESPECÍFICOS DE LAZER}

Os equipamentos não específicos são aqueles que foram pensados para outros fins, mas que são utilizados para a prática do lazer. Alguns exemplos é a casa, a rua, a escola e até mesmo, o ambiente de trabalho.

Todas as pesquisas dão conta de que a grande maioria da população, notadamente nos grandes centros urbanos, desenvolve suas atividades de lazer, prioritariamente, no ambiente doméstico. O lar é o principal equipamento não específico de lazer, ou seja, um espaço não construído de modo articular para essa função, mas que eventualmente pode cumpri-la (MARCELLINO, 2006, p. 29).

O lar ou a casa estão cada vez mais sendo vistos como equipamentos de lazer, talvez pelos efeitos nocivos causados pelo processo de desenvolvimento das cidades, como o transito dos grandes centros urbanos, a violência ou até mesmo as condições financeiras para a prática do lazer.

Um ambiente curioso e que a cada dia vem sendo apropriado para a prática do lazer é o ambiente de trabalho. Grandes empresas vêm adequando seu espaço para o lazer de seus funcionários. Podemos citar como exemplo a Google, que adaptam algumas salas com jogos, espaços de leitura, relaxamento, com várias instalações que possam ser utilizadas pelos funcionários fora do horário de produção, nos tempos de pausas, horário de almoço e fim de expediente, conforme apresentado na (FIGURA 1): 
Figura 1: Espaço de convivência na Empresa Google

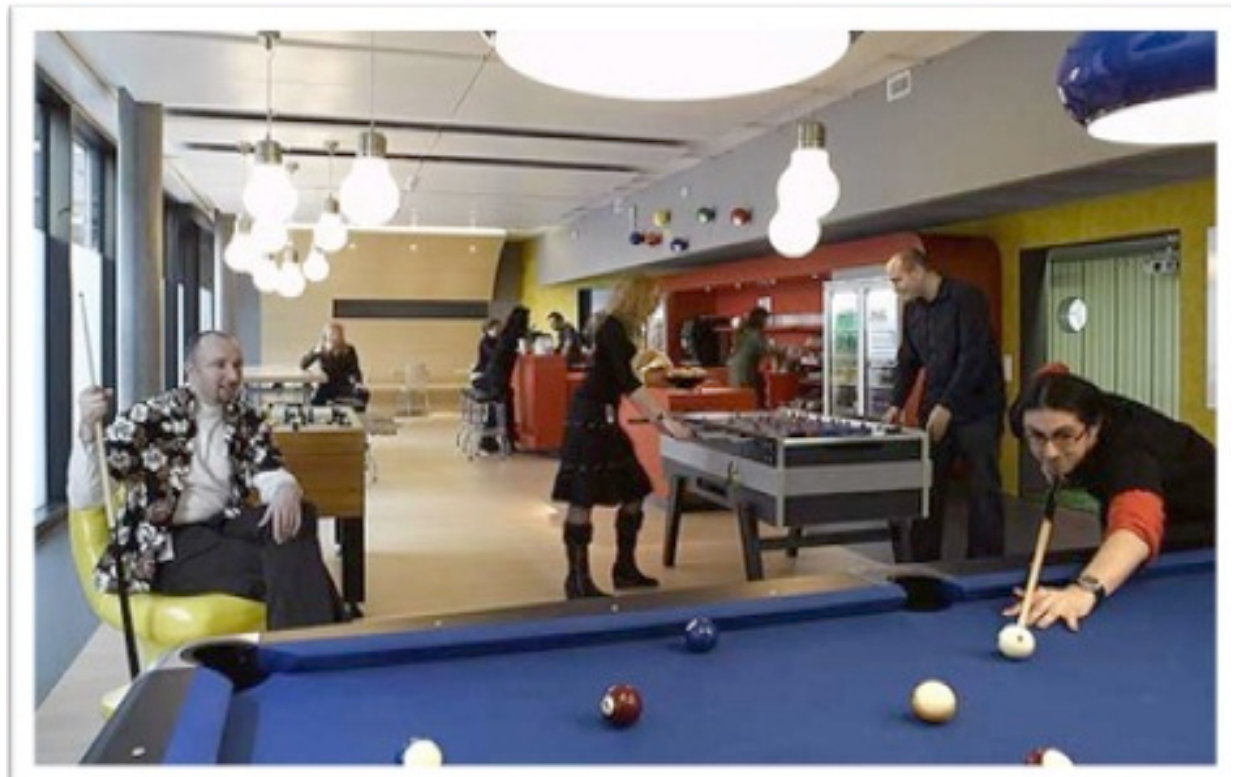

Fonte: Blog Decorarte Brum, 2012.

Esse processo de apropriação do espaço de trabalho para o lazer dos funcionários é um ponto de conquista trabalhado pelo endomarketing da empresa, uma vez que os funcionários possuem um ambiente de trabalho com esses aspectos "relaxantes" há uma contribuição para o crescimento da produtividade.

As ruas, enquanto equipamentos de lazer são utilizadas de forma a proporcionar uma socialização da população. Muitas pessoas organizam festas que são desenvolvidas nas ruas. Já em relação às escolas, estas possuem uma variedade de equipamentos em seu espaço físico que proporciona o lazer dos alunos como as quadras de esportes, pátio, auditórios, lanchonetes, área de convivência e etc. Outro aspecto interessante é o vínculo que a escola pode ter com a comunidade local por meio do oferecimento de programas nos fins de semana como exemplo, o Programa Escola Aberta do Ministério da Educação. O programa apoia a abertura das escolas nos finais de semana, onde potencializa a parceria entre escola e comunidade para ocupar criativamente o espaço escolar com atividades educativas, culturais, esportivas, de lazer e de formação profissional (BRASIL, 2012). 
Mas a abertura das escolas para essa prática ainda não é bem desenvolvida nas pequenas cidades do interior do estado talvez pelo temor dos riscos de depredação do espaço.

O bar, nos dias atuais, ainda é visto com algum preconceito por muitos, visto que tem uma visão de ambiente de consumo de bebidas alcoólicas, mas essa visão aos poucos está sendo modificada. O ambiente do "barzinho" é um dos mais utilizado por jovens e casais que procuram um espaço de contato mais próximo com outras pessoas, alguns desses ambientes oferecem uma programação diversificada de apresentações culturais que fornecem momentos de entretenimento, dentre outros atrativos.

Marcellino (2006) apresenta duas questões importantes que devem ser levadas em consideração quando se fala da precariedade da utilização dos equipamentos não específicos de lazer:

1- A falta de política habitacional que deveria estimular o uso do espaço como área de lazer. "O que não é fácil num país como o nosso, com alto déficit habitacional, e que deve, portanto, estimular alternativas criativas em termos de áreas coletivas" (MARCELLINO, 2006, p. 31).

2- O desenvolvimento de políticas de animação para o estimulo do uso dos espaços específicos de lazer pela população.

Nas cidades brasileiras, especificamente na realidade das cidades do interior do nordeste de pequeno e médio porte, o que se pode observar, a priori é que o espaço onde é praticado esse lazer está restrito nas praças e quadras de esportes e nem sempre esses equipamentos estão em seu estado otimizado, ocasionando assim um mau uso e visão da população em sua referência, tendo como exemplo o caso da cidade de Currais Novos - RN.

\section{CARACTERIZAÇÃo dA ÁREA DE ESTUdO: O MUNICÍPIO DE CURRAIS NOVOS/ RN}


O município está localizado na Mesorregião Central Potiguar à $172 \mathrm{~km}$ da capital Natal representado na Figura 2. Situado na Região Seridó, com geografia rica no ponto de vista histórico, social, físico, ambiental, econômico e turístico. Uma área de 864,34 km² equivalente a $1,67 \%$ da superfície estatal. Em seus limites estão ao Norte as cidades de Lagoa Nova e Cerro Corá, ao Sul a cidade de Acari e a divisa do estado da Paraíba, ao Leste estão Campo Redondo e São Tomé e ao Oeste a cidade de São Vicente. De acordo com o último censo a cidade possuía uma população de 42.652 mil habitantes (IBGE, 2012).

Figura 2: Localização do município de Currais Novos no mapa do Rio Grande do Norte

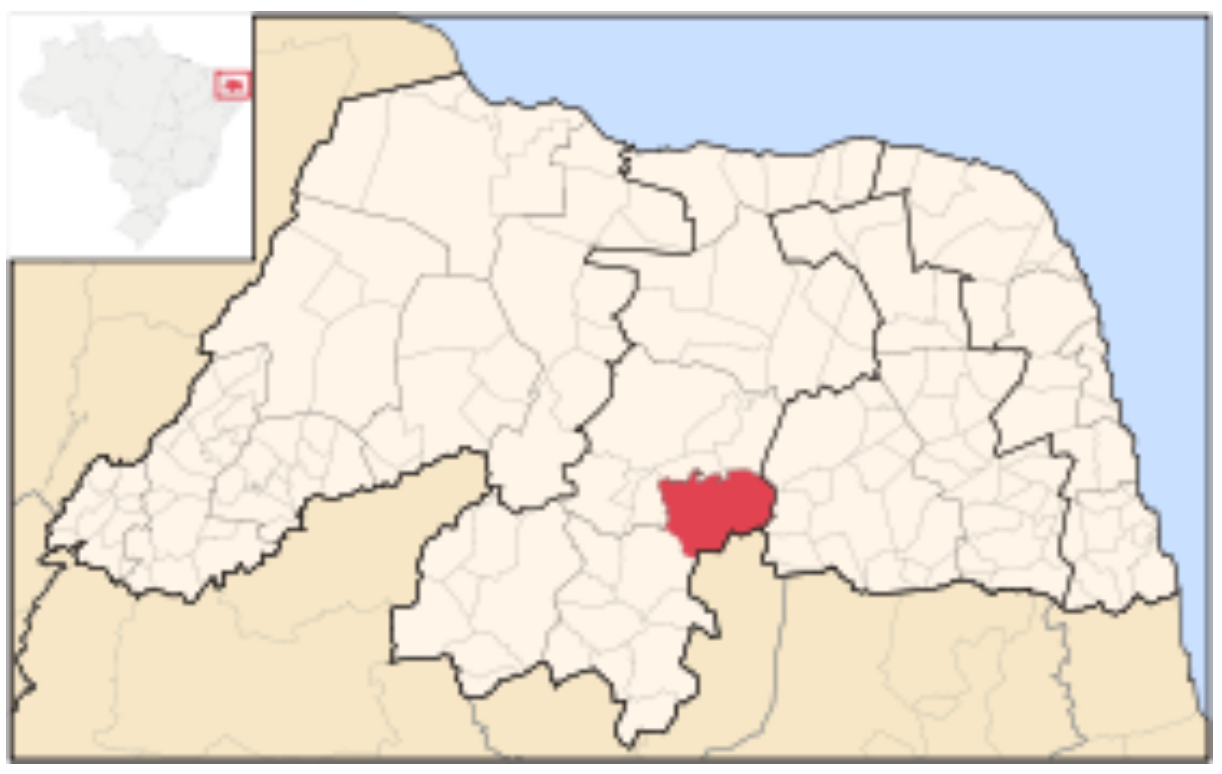

Fonte: Site Viagem de Férias, 2012.

Buscando o desenvolvimento do Turismo na localidade, atualmente a cidade participa do Roteiro Seridó onde busca comercializar seus diversos atrativos. A cidade possui serras, picos, barragens, rios, açudes, lagos, inúmeras formações rochosas que incrementam o Turismo de Aventura como também são fontes da produção artesanal local; pinturas rupestres e museus que ajudam a conhecer a história da população; Minas de Scheelita, Ouro, Tungstênio que tiveram significante importância no desenvolvimento econômico da cidade, que o turista pode conhecer de perto o local de extração em alguns túneis desativados e 
abertos ao fluxo turístico; e ainda, os diversos eventos, sendo estes os principais indutores do Turismo na região, dentre eles o Forronovos, Carnaxelita, Festa de Padroeiros e Vaquejadas (ROTEIRO SERIDÓ, 2012). ${ }^{3}$

A cidade dispõe de 15 bairros na sua estrutura urbana, são eles: Paizinho Maria, Parque Dourado I e II, Centro, Radir Pereira, José Dantas de Araújo, Dr. José Bezerra, Valfredo Galvão, Bairro JK, Santa Maria Gorete, Cel. Manuel Salustino, Antônio Rafael, Professor Gilberto Pinheiro, Silvio Bezerra e seu mais novo bairro o Loteamento Santa Tereza (SIDY'S, 2012). Estes bairros constituíram-se campo de estudo desta pesquisa.

Diante da necessidade de conhecer a visão do curraisnovense sobre os espaços públicos da cidade no âmbito da prática do lazer, quais os equipamentos a população gostaria que fossem oferecidos e como se dá o processo de apropriação e uso dos espaços disponíveis na cidade, foi realizado um levantamento das áreas públicas de lazer disponíveis na localidade e alguns espaços semi-públicos que foram delimitados de acordo com a opinião do entrevistados, pois o foco da pesquisa é nos espaços públicos. Os semi-públicos apresentados servirão para descrever o panorama da prática do lazer dos munícipes, detalhando os principais lugares que a população frequenta para desenvolver a atividade.

Percebe-se que para instigar a população a praticar o lazer é necessário que os espaços e equipamentos urbanos públicos, a partir das políticas públicas, ofereçam diversas atividades que abrangem os vários interesses dos indivíduos. Diante do exposto, buscou-se conhecer a percepção da população curraisnovense no processo de apropriação dos espaços públicos urbanos da cidade de Currais Novos, para traçar um panorama atual das atividades de lazer praticadas nas áreas de lazer, bem como das necessidades da população local frente às ofertas de equipamentos de lazer públicos.

\footnotetext{
${ }^{3}$ O Roteiro Seridó é um programa desenvolvido pelo SEBRAE com apoio dos governos Federal e Estadual que busca divulgar os atrativos turísticos da região Seridó como forma de Roteiro Integrado. 


\section{ANÁliSe dOS RESULTADOS DA PESQUISA: PERCEPÇÃO DA POPULAÇÃO}

Foram aplicados 160 formulários com a população de diferentes faixas etárias, sexo e classe social que utilizam dos espaços públicos para a prática do lazer em Currais Novos. Buscou-se contemplar na pesquisa, habitantes de todos os bairros constituintes da cidade de Currais Novos, não podendo alcançar apenas um bairro por motivo de distância e ser um loteamento ainda em construção, o loteamento Santa Tereza.

\subsection{PERFIL DOS ENTREVISTADOS}

A prática do lazer é direito de todos e não exclui sexo nem idade, há apenas uma seleção no uso dos equipamentos direcionados à prática do lazer quando estes são privados. Nos 160 formulários aplicados, pode-se observar uma equivalência no quesito sexo das pessoas entrevistadas que utilizam os espaços de lazer da cidade, onde $55 \%$ dos entrevistados foram do sexo feminino e $45 \%$ do sexo masculino.

Em relação à faixa etária buscou-se entrevistar pessoas com mais de 18 anos por ser uma idade que muitos já possuem uma opinião formada e certa independência em seus atos. Pode-se constatar que 50\% dos entrevistados possuem entre 18 e 25 anos, 33,12\% de 26 a 40 anos, 9,4\% de 41 a 60 anos e 7,5\% acima de 60 anos. Os idosos estão cada vez mais utilizando os espaços públicos para o lazer devido a oferta de infraestruturas acessíveis para a classe.

Durante a aplicação também foi observado que muitos dos habitantes que frequentam esses espaços de lazer são crianças e adolescentes, mas como não se enquadravam no perfil dos entrevistados essa estatística não poderá ser analisada, embora seja um público significativo.

A escolha por incluir os itens de estado civil, ocupação e nível de renda na pesquisa foi devido estes itens influenciarem na escolha do tipo de equipamento para a prática 
do lazer, bem como o horário de utilização. Em relação ao estado civil, $70,62 \%$ dos entrevistados são solteiros, $27,50 \%$ são casados e 1,9\% são viúvos. Essa porcentagem evidencia a escolha por locais mais badalados, com maior concentração de pessoas da mesma faixa etária ou locais mais calmos, com alguns serviços oferecidos diferenciados.

Foram entrevistados 79 estudantes abordados nas praças e na UFRN equivalendo a $49,37 \%$ dos entrevistados, deste percentual $96,20 \%$ não possuem renda e $3,8 \%$ possuem uma renda de até 1 salário mínimo. Fato que pode constatar a presença significante dos estudantes nas praças e quadras de esportes visto que são locais públicos, sem nenhuma taxa de utilização cobrada.

Além dos estudantes, foram entrevistados funcionários públicos somando um percentual de 26,25\%, autônomos representados por 8,75\%, aposentados com 6,9\%, desempregados $2,5 \%$ e outras ocupações $6,25 \%$. Com exceção dos desempregados, todas as ocupações citadas possui um nível de renda acima de 1 salário mínimo.

O fator renda é um dos elementos decisivos na escolha do equipamento de lazer, pois quando um indivíduo possui uma renda relativamente alta, isso possibilita a utilização de melhores espaços de lazer, provavelmente privados. Este percentual configura o cenário da utilização dos espaços públicos e semi-públicos de lazer da cidade observados durante a aplicação da pesquisa. A maioria do público que utiliza as praças e as quadras de esportes são estudantes, e os espaços semi-públicos são geralmente utilizados por pessoas que possuem renda, não deixando de ressaltar que os estudantes também utilizam desses espaços semipúblicos, mas com menor frequência.

\subsection{VISÃO DA POPULAÇÃO EM RELAÇÃO AOS ESPAÇOS DE LAZER DA CIDADE}

Durante a aplicação dos formulários procurou-se entrevistar pessoas de todos os bairros da cidade, para ter um panorama geral da visão da população curraisnovense sobre o 
lazer, só não sendo possível a opinião de pessoas de apenas 1 bairro como justificado anteriormente.

A Figura 3 ilustra a divisão dos bairros do município delimitando a posição dos equipamentos de lazer no território. Os espaços semi-públicos e privados identificados, por mais que não se enquadrem no foco da pesquisa, são lugares bastante procurados pela população para a prática do lazer relatados na aplicação dos formulários de pesquisa.

Figura 3: Identificação dos espaços de acordo com os bairros do município de Currais Novos

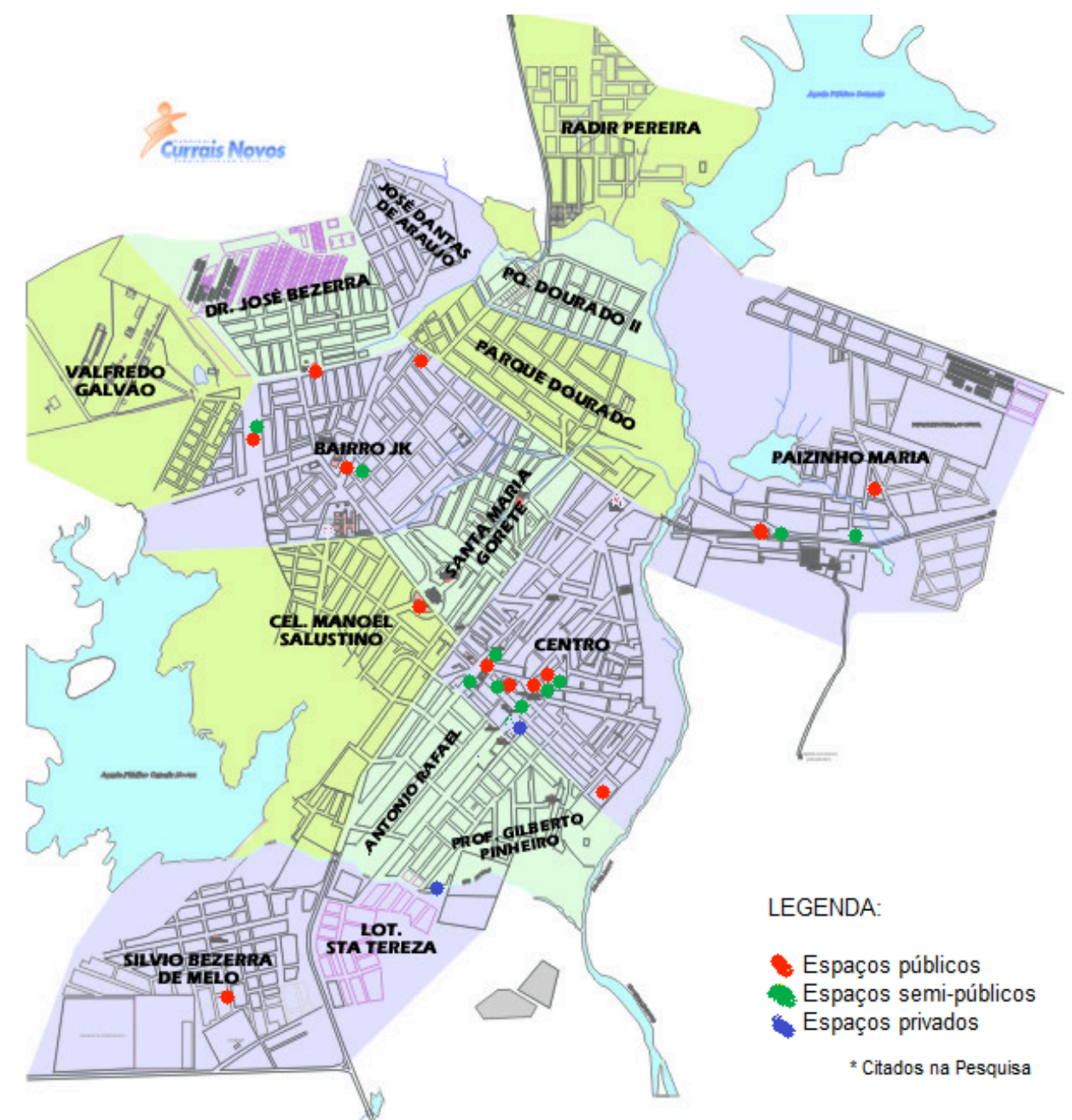

Fonte: Sidy's TV a Cabo. Adaptado pelas autoras, 2012. 
A primeira pergunta do formulário era direcionada para o bairro do entrevistado, sendo questionado qual o equipamento de lazer do bairro ele considera mais utilizado pela população para saber se as pessoas tem conhecimento das ofertas de lazer de seus bairros.

A população do Centro da cidade, $60 \%$ dos entrevistados afirmaram que a Praça Cristo Rei é o equipamento de lazer mais utilizado pela população do bairro. Além de citarem a Praça como principal oferta do bairro, alguns entrevistados mencionaram a Praça Cristo Rei juntamente com outro equipamento como focos do lazer do centro, $20 \%$ informaram que os equipamentos mais utilizados são a Praça Cristo Rei e Praça Tomaz Salustino e outros 20\% indicaram a Praça Cristo Rei e os Quiosques da Praça de Artesanato Wilma Maia de Faria.

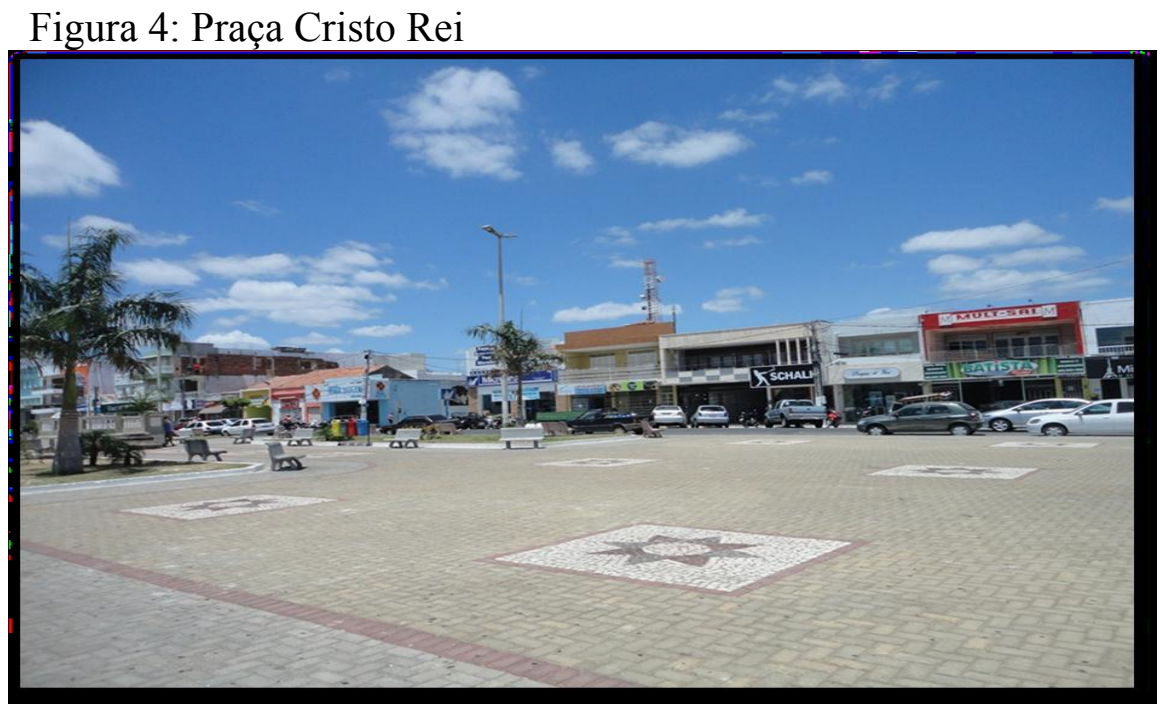

Fonte: Pesquisa de campo, 2012.

Pode-se constatar que $100 \%$ da população do centro de Currais Novos indica a Praça Cristo Rei como o espaço público de lazer mais utilizado pela população do bairro como também de toda a cidade.

No bairro Paizinho Maria, 60\% dos entrevistados responderam que o Ginásio Poliesportivo Elisão é o mais utilizado para o lazer da população local, 10\% indicaram a Praça Aproniano Pereira e 30\% afirmaram que a Praça Aproniano Pereira juntamente com os famosos espetinhos e quiosques são os espaços mais utilizados para a prática do lazer. 


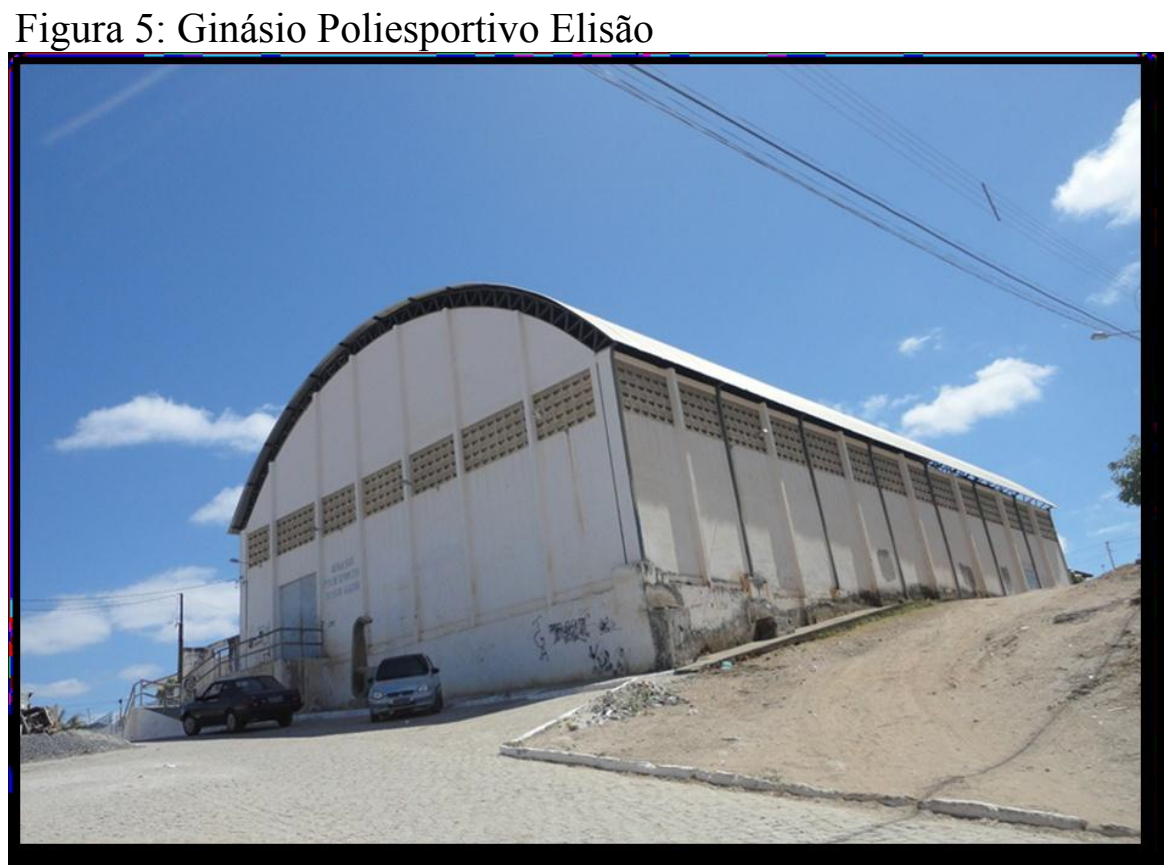

Fonte: Pesquisa de campo, 2012.

O Paizinho Maria é um bairro periférico e relativamente de população carente e é um dos poucos bairros periféricos da cidade que contem espaços de lazer. O bairro Antônio Rafael, $80 \%$ da população afirmam não ter áreas de lazer neste bairro e $20 \%$ responderam que a área de lazer mais utilizada é a Praça Cristo Rei. A partir daí pode-se observar que há um equívoco por parte da população em identificar as áreas de lazer da cidade e do seu bairro em específico, talvez pela divisão geográfica dos bairros ou até mesmo pela a proximidade dos espaços.

Essa aproximação entre os bairros com referência ao espaço de lazer pode ser visto como uma estratégia política na delimitação do espaço, tendo em vista a economia de investimentos que futuramente pode ser desapropriados pela população no uso para o lazer.

O próximo bairro a ser explanado é o Valfredo Galvão, onde $66,67 \%$ da população local relacionaram o Largo Júnior Toscano como principal área de lazer do bairro, caracterizando mais um equívoco da população na distinção das áreas de lazer dos bairros, pois o Largo Júnior Toscano está localizado no Bairro JK, pelo fato do espaço está localizado 
próximo à divisa dos bairros há esse engano, $16,67 \%$ não souberam responder e os outros $16,67 \%$ afirmaram que não existe área de lazer no Valfredo Galvão.

Figura 6: Largo Júnior Toscano

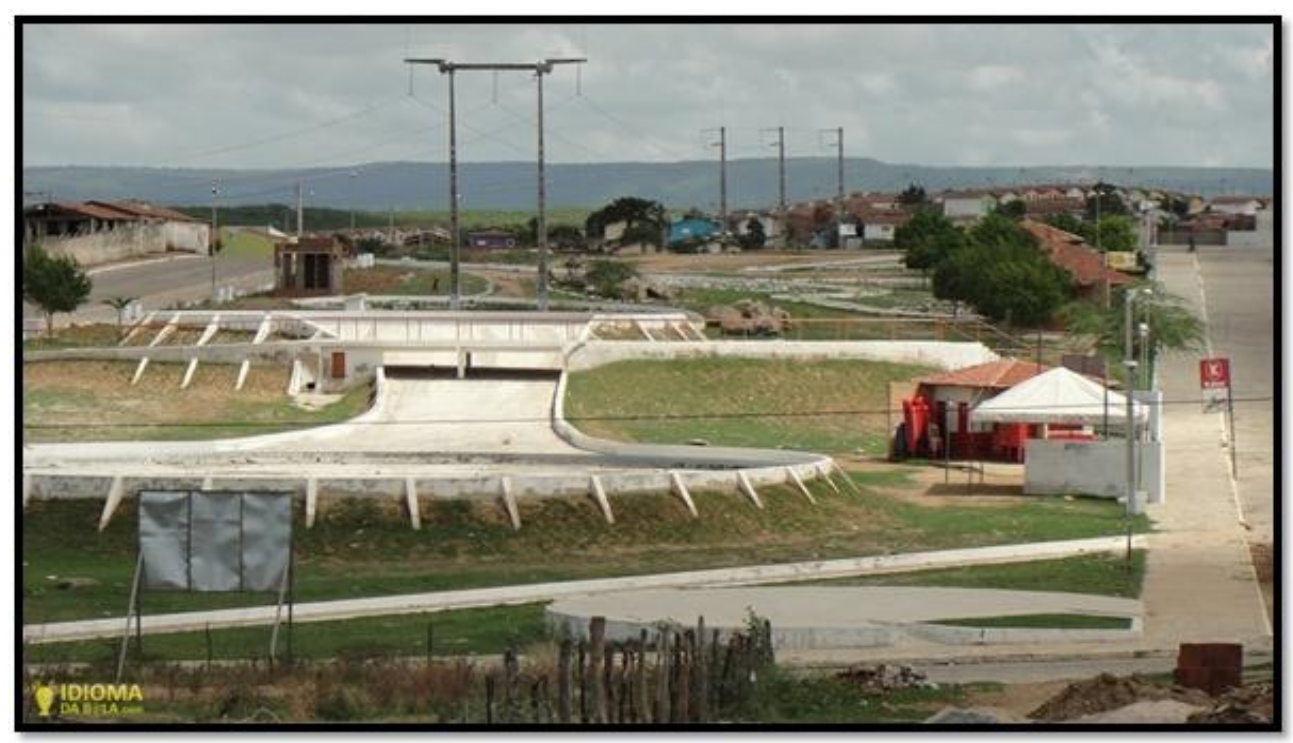

Fonte: VARELA, 2012.

Dos entrevistados no bairro Cel. Manuel Salustino, 42,86\% indicaram a Praça Tetê Salustino como área de lazer mais utilizada e 57,14\% afirmaram que não existe área de lazer no bairro. A apropriação da Praça Tetê Salustino é favorecida pela promoção de projetos desenvolvidos pela SEMEC como apresentações culturais e estudantis.

Figura 7: Praça Tetê Salustino

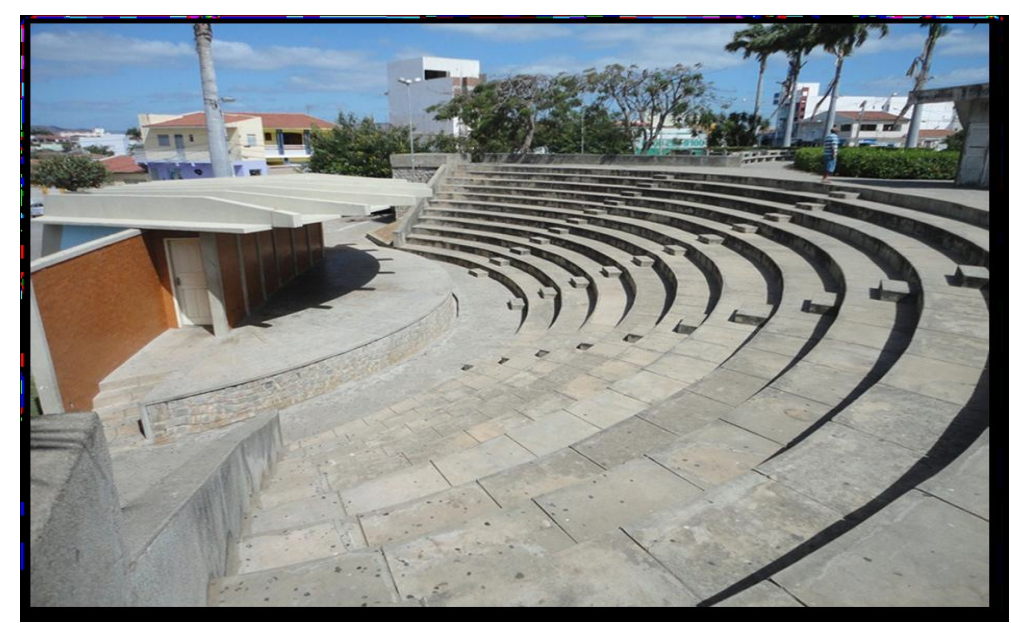

Fonte: Pesquisa de campo, 2012. 
No bairro Santa Maria Gorete, $100 \%$ da população local informaram que não existe área de lazer no bairro. Essa realidade pode ser percebida também com os resultados obtidos na pesquisa com entrevistados em outros bairros da cidade como o Radir Pereira e José Dantas de Araújo, ambos os bairros não dispõem de ofertas de espaços públicos de lazer.

Um fator que justifica a ausência dos equipamentos de lazer nesses dois últimos bairros citados é por eles estarem em uma região periférica da cidade, a concentração maior dos equipamentos de lazer está localizada nos bairros mais centrais, um aspecto importante que deve ser revisto pelo poder público, pois a Lei Orgânica Municipal (1990) regulamenta a constituição de espaços de lazer nas áreas periféricas da cidade. Essa má distribuição dos equipamentos obriga a população se deslocar até o centro da cidade para poder usufruir de um equipamento de lazer, onde muitas vezes esse deslocamento é dificultado por alguns fatores de risco como a violência e transporte. Mas esse panorama de má distribuição dos equipamentos é notável em muitas cidades, porque não dizer em sua maioria, e comprovado cientificamente por pesquisas acadêmicas.

No bairro Professor Gilberto Pinheiro também retrata a falta de investimento por parte do poder público na constituição de espaços públicos de lazer para a população do bairro. Os espaços de lazer disponíveis são áreas privadas que restringem certa parte da população, a Associação Atlética Banco do Brasil - AABB é um exemplo destas, 42,86\% da população local afirmam que a AABB é o espaço de lazer mais utilizado do bairro e 57,14\% afirmam que tanto a AABB como o AERO Clube são os espaços mais utilizados pela população local.

Essa presença dos espaços semi-públicos e privados na pesquisa aplicada à população como um dos espaços mais utilizados pela comunidade é interessante, pois pode-se constatar a carência de investimentos ou a desvalorização dos espaços públicos de lazer frente ao poder público e a população local, respectivamente. 
A cidade possui os bairros Parque Dourado I e II, na pesquisa será analisado como apenas 1, pois são bairros pequenos e ligados, onde as infraestruturas públicas contidas são oferecidas em conjunto. Entre os entrevistados $60 \%$ responderam que o Ginásio Poliesportivo Senador Agenor Nunes de Maria (Agenozão) é o mais utilizado no bairro para o lazer, 20\% afirmam que não existe área de lazer e $20 \%$ responderam que um campo de futebol improvisado em um terreno baldio é o espaço de lazer do bairro. Mais uma interpretação equivocada da população devido à proximidade dos bairros é a respeito ao Agenozão, pois ele pertence ao bairro JK.

Figura 8: Ginásio Poliesportivo Senador Agenor Nunes de Maria (Agenozão)

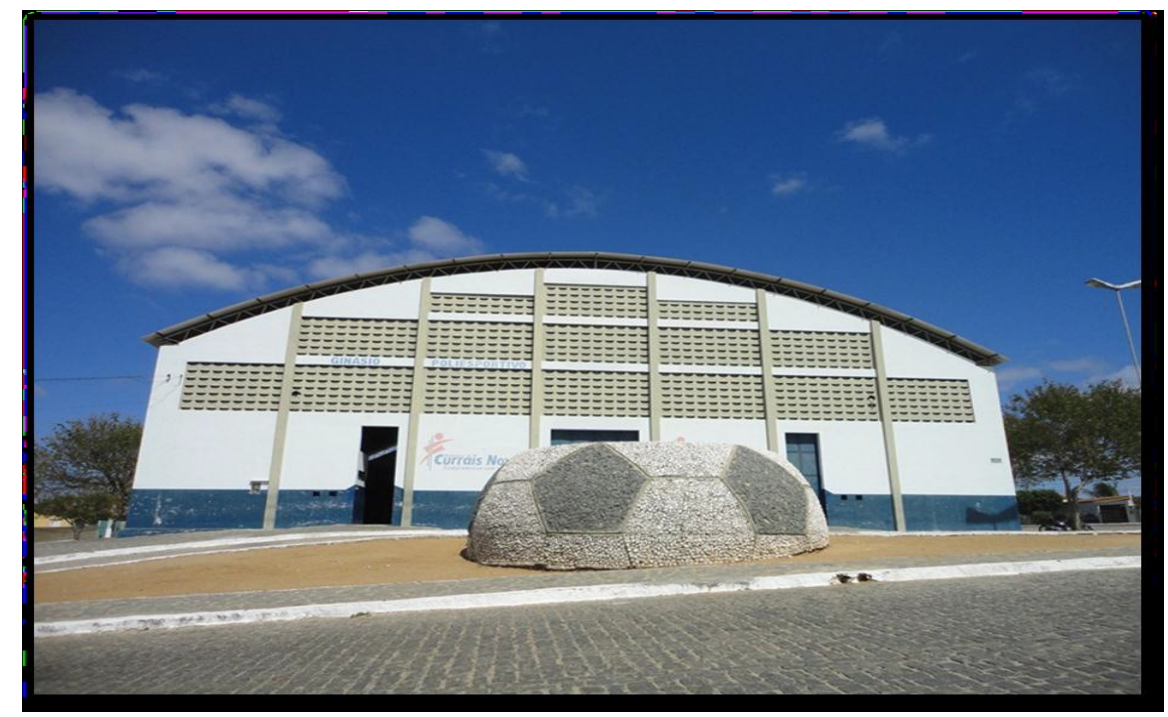

Fonte: Pesquisa de campo, 2012.

No bairro Dr. José Bezerra, 40\% dos entrevistados caucionam que a Praça de Skate é a mais utilizada pela população do bairro e 60\% afirmam que não existe área de lazer. Geograficamente a Praça de Skate está localizada na divisa dos bairros JK e Dr. José Bezerra ficando claro o motivo da confusão. 


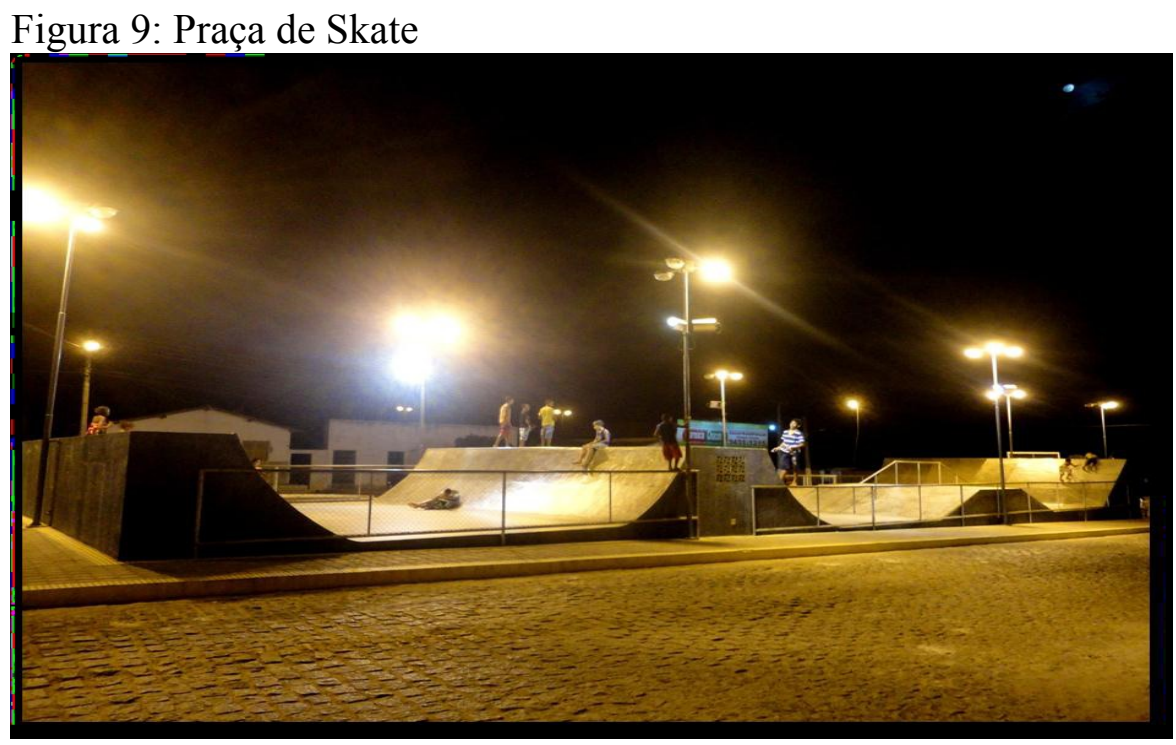

Fonte: Pesquisa de campo, 2012.

O Bairro Silvio Bezerra de Melo é um dos poucos bairros periféricos que possuem área de lazer pública, o Ginásio Poliesportivo Padre José Dantas Cortez (Cortezão) que aparece com 100\% das menções da população local.

E o bairro JK, um dos centrais e com maior concentração de espaços públicos e semi-públicos de lazer, os entrevistados classificam os "espetinhos" como equipamento de maior utilização da população com 50\% das indicações, o Ginásio Poliesportivo Senador Agenor Nunes de Maria com 16,67\%, e as Praças que incluem o Largo Júnior Toscano, Praça de Skate e Praça da Imaculada com 33,34\%.

Com essa ilustração pode-se perceber que a população de Currais Novos ainda possui certo equívoco em identificar os equipamentos de lazer de cada bairro, até mesmo do próprio bairro onde reside, seja ele por uma má distinção de divisas ou até mesmo por falta de interesse, característica que pode ser percebida durante a aplicação dos formulários.

Essa distribuição de espaços públicos de lazer constituídas nas divisas dos bairros pode ser visto como uma estratégia do poder público em alcançar o público de dois bairros conjuntos com o mesmo equipamento oferecido, diminuindo assim os gastos públicos. Essa técnica pode até ser considerada como positiva para as questões de planejamento, visto que um desses bairros periféricos tem uma extensão territorial pequena para o oferecimento de um Licere, Belo Horizonte, v.17, n.3, set/2014 
espaço de lazer específico para a população local, ocasionando assim uma má utilização e valorização pelos munícipes locais e gerando um fluxo marginalizado no espaço.

Partindo por uma sequencia lógica, foi levantado o questionamento de qual/quais equipamentos de lazer da cidade o entrevistado mais utiliza, com que frequência e quais atividades costumam praticar nessas áreas para formular um panorama de como as áreas de lazer estão sendo apropriadas pela população na prática do lazer.

Pode ser observado que a população curraisnovense utiliza quase na mesma proporção basicamente de três tipos de equipamentos de lazer da cidade Gráfico 1, as praças, quadras de esportes e quiosques distribuídos em locais estratégicos dos bairros da cidade, mas com maior concentração no centro e no bairro JK.

Gráfico 1: Equipamento de lazer mais utilizado na cidade na opinião da população curraisnovense

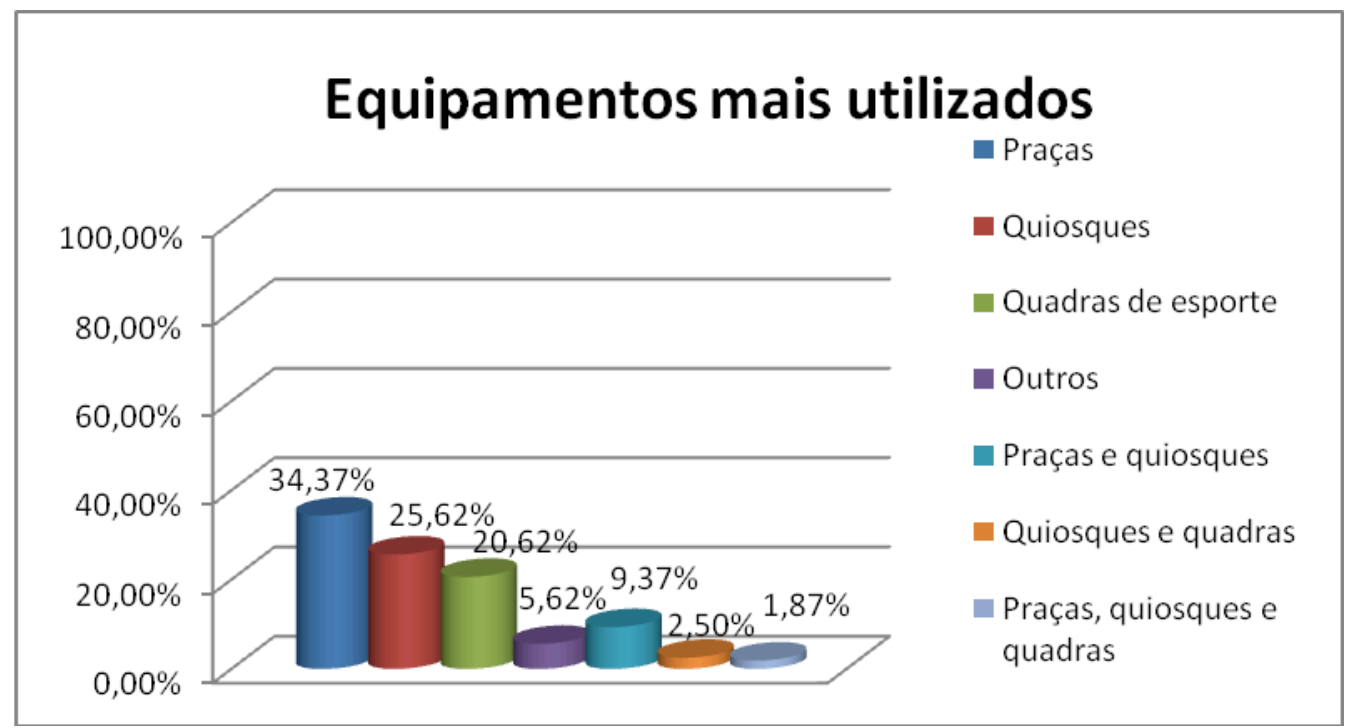

Fonte: Pesquisa de campo, 2012.

A frequência de utilização se configura em mais de uma vez por semana com $55 \%$ da opinião dos entrevistados, 36,25\% utilizam os espaços apenas 1 vez por semana e somente $8,75 \%$ utilizam todos os dias. Desta frequência, $94,37 \%$ utilizam os espaços durante a noite e 
apenas $6,25 \%$ durante o dia, demonstrando uma clara utilização em períodos que sugerem tempo livre dos entrevistados.

Os tipos de atividade que os entrevistados realizam nos espaços justificam o percentual apresentado, pois as atividades desenvolvidas durante o dia são as caminhadas e ginásticas nas praças e jogos de futsal nas quadras de esportes. Já as atividades desenvolvidas durante a noite são passeios de bicicleta, conversas com os amigos nas praças, lanches com a família, namorados e amigos nos quiosques e espetinhos, como também caminhadas nas praças e jogos nos ginásios.

O público idoso curraisnovense esta cada vez mais frequentando as praças em busca de melhoria da qualidade de vida na participação de projetos desenvolvidos pela Prefeitura Municipal de Currais Novos que ofertam a prática de ginástica e caminhada na Praça Cristo Rei. O público que frequenta esse projeto é diversificado, há idosos, adultos e jovens.

Foi questionado se havia alguma impossibilidade de uso dos equipamentos de lazer da cidade pelo indivíduo entrevistado, $81,25 \%$ afirmaram que NÃO e 18,75\% disseram que SIM.

A partir desta questão procurou-se identificar quais as dificuldades enfrentadas no uso dos equipamentos da cidade, obtendo-se como resultado os fatores de violência, distância e acessibilidade das ofertas. Esses fatores são comuns nas demais cidades do país, mas com o apoio do poder público na elaboração de políticas públicas e melhorias no $\mathrm{PD}$, o índice desses aspectos negativos podem ser diminuídos e assim contribuir para um bom uso e apropriação dos espaços para a prática do lazer como também na melhoria da qualidade de vida da população.

De acordo com a opinião dos entrevistados, a cidade de Currais Novos NÃO apresenta espaços de lazer adequados para o uso da população, representado por $48,61 \%$ das 
afirmações, 39,52\% julgam os espaços EM PARTES adequados e apenas 11,87\% disseram que os equipamentos ofertados são adequados, essa percepção da população é confirmada no item avaliativo a seguir.

Diante desse pressuposto, foi questionado à população quanto às condições estruturais dos espaços públicos da cidade, como o indivíduo avalia a infraestrutura desses espaços, $8,12 \%$ avaliam como péssima, $63,75 \%$ como regular, $28,12 \%$ julgam como boa e nenhum dos entrevistados avaliaram as estruturas dos espaços públicos de lazer da cidade como ótima. Essa avaliação demonstra como os espaços são vistos pela população e configura-se como um dos principais fatores que negativam a visão da população frente aos espaços. Ainda nesse aspecto, foi perguntada a opinião do entrevistado sobre o que falta para melhorar a prática do lazer na cidade, grande parte das respostas está voltado para o poder público, com o maior investimento por parte da iniciativa pública e privada na constituição de novos equipamentos de lazer, principalmente tentando atender às necessidades da população.

Pode-se perceber que a população observa a carência de investimentos em áreas de lazer e a falta de interesse por parte do poder público na manutenção e otimização desses espaços para que o lazer seja valorizado.

No intuito de conhecer a percepção da população sobre a relação do lazer com o turismo foi perguntado sobre a importância que os espaços de lazer têm para o fomento da atividade turística, 90,62\% afirmaram que os espaços de lazer possuem um significativo potencial de fomento da atividade turística e apenas 9,37\% responderam EM PARTES. Essa perspectiva ilustra que a população, ao contrário que muitos pensam, tem uma certa visão e conhecimento a respeito da atividade turística.

Estas descrições significativas constatadas através dos formulários aplicados apontam para uma necessidade de melhor organização dos espaços e atividades de lazer da cidade. 


\subsection{PROGRAMAS E ATIVIDADES COMO ESTRATÉGIA DE FOMENTO DO LAZER E DA ATIVIDADE TURÍSTICA}

Diante dos resultados adquiridos a partir das pesquisas apresentadas, pôde-se chegar a um panorama da disponibilidade da cidade para a prática do lazer. Não são muitos os programas e as atividades desenvolvidas pelo poder público na área do lazer, mas o objetivo desse é apresentar os projetos que já são desenvolvidos e dar uma contribuição para otimização destes, de acordo com a necessidade da população identificada durante a pesquisa, bem como propor a inclusão de novos projetos na programação de responsabilidade dos gestores.

A maioria das atividades desenvolvidas hoje na cidade que promovem o lazer é de cunho esportivo e muitas dessas atividades são direcionadas aos estudantes, deixando de atingir um considerável número de pessoas, ficando apenas os eventos como opção de lazer oferecido pelo poder público. Essa realidade justifica a utilização massificadora dos espaços semi-públicos da cidade como opção de lazer identificada na pesquisa realizada com a população.

A prática do lazer é direito de todos e o poder público tendo autonomia pelos espaços públicos de uma cidade deve promover esse direito para a população, já que também consta em suas leis municipais essa preocupação com o fenômeno. Além de ser visto como um simples compensador de necessidades pessoais pode ser considerado um grande aliado do turismo, pois tem a capacidade de agregar valores à atividade, saindo positivamente ambos os lados. Algumas das propostas desenvolvidas pela Secretaria de Educação e Cultura na Subcoordenadoria de Esporte e Lazer são bem interessantes e serão apresentadas a seguir.

As Férias Quentes é um projeto desenvolvido durante as férias de fim de ano, do mês de dezembro à janeiro. É um projeto interessante, pois envolve 4 bairros da cidade dentre eles 3 são periféricos, o Paizinho Maria, Dr. José Bezerra e Silvio Bezerra de Melo onde 
possuem a maior carência de equipamentos de lazer apresentado no levantamento dos espaços passíveis de uso para o lazer e o bairro mais central JK, cada bairro cedia uma etapa diferente.

Para participar, os alunos têm que efetuar uma inscrição antes do término do ano letivo e como regra, os inscritos tem que participar de todas as oficinas oferecidas. As Férias Quentes é uma espécie de circuito onde cada bairro representa uma etapa, que acontecem em dias diferentes, contemplando todo o período de férias.

Outro aspecto interessante que deve ser ressaltado é a utilização de espaços não específicos de lazer para a realização do evento, neste caso as escolas. Mais adiante, será apresentado outro projeto que pode ser adaptado e oferecido nas escolas da cidade, visto que possui grande número disponível e presente na maioria dos bairros.

Dentre as oficinas oferecidas pode-se destacar a de jogos de raciocínio rápido Figura 10 como dominó, xadrez e dama; oficina de música com o conhecimento básico sobre os instrumentos musicais e a possibilidade de "tocar" pela primeira vez, instigando o gosto pela música.

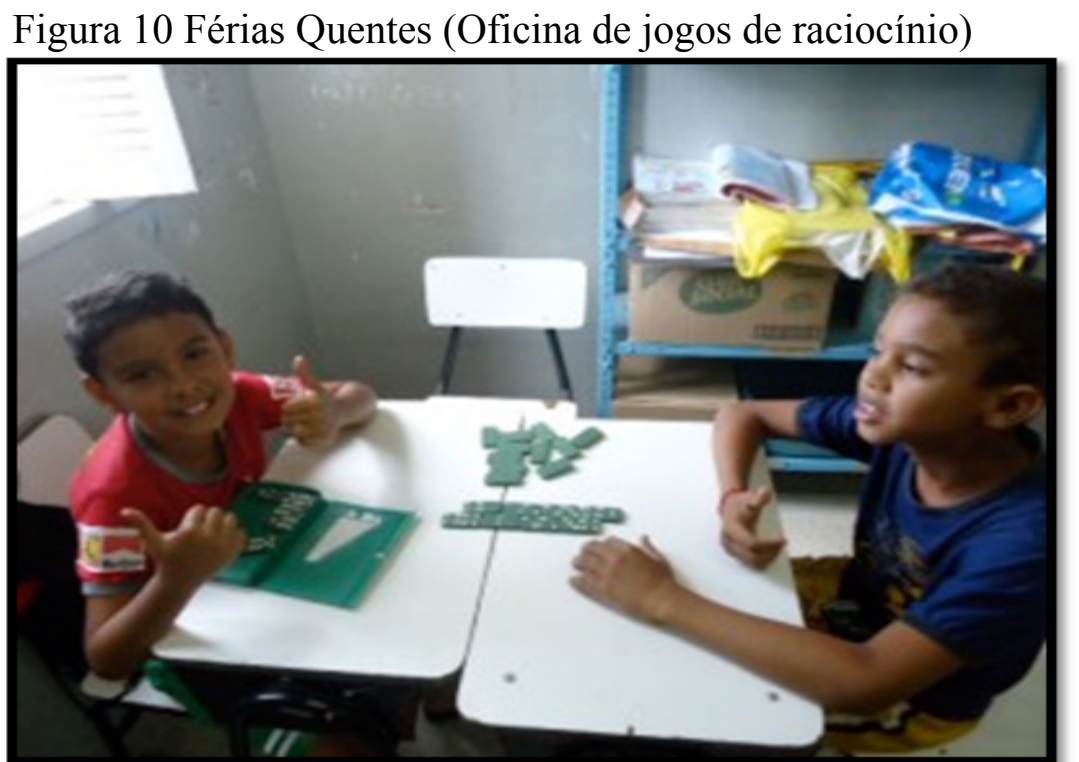

Fonte: Subcoordenadoria de Esporte e Lazer, 2012.

Oficinas de esporte com campeonato de jogos cooperativos como futsal, vôlei, queimada e bandeirinha, e artes maciais como karatê (FIGURA 11). 
Figura 11: Férias Quentes (Oficina de Artes Maciais)

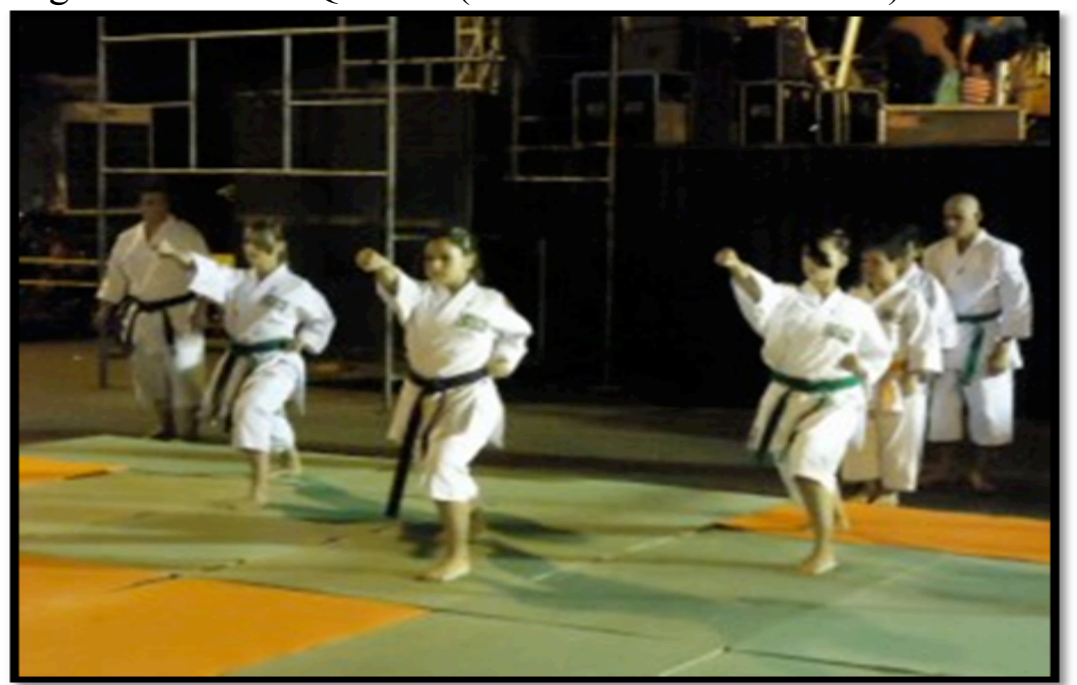

Fonte: Subcoordenadoria de Esporte e Lazer, 2012.

A identificação dos participantes é através de fitinhas coloridas que cada cor representa uma oficina, ficando fácil a organização e a distribuição das crianças nas oficinas e na merenda.

As Férias Quentes é uma ótima proposta vista por vários fatores:

- Proporciona lazer às crianças e adolescentes que frequentam a escola;

- Utiliza os equipamentos não específicos, como a escola, para a promoção do lazer gratuito à população;

- Proporciona o lazer em alguns bairros periféricos da cidade, buscando a compensação da falta de investimento de equipamentos específicos de lazer, mesmo não compreendendo todos os bairros periféricos que não dispõem de tal oferta;

- Trabalha a visão da criança e do adolescente a respeito do cooperativismo e a importância da prática do esporte para a saúde.

Propõe-se a inclusão de oficina de reciclagem para trabalhar as questões de Educação Ambiental, conscientizando e sensibilizando sobre a importância do Meio Ambiente. Outra ideia seria trabalhar o lado artístico dos alunos com a organização de peças 
teatrais educativas que pudessem expor a realidade focando nos problemas atuais como drogas, violência, meio ambiente e exploração sexual, onde poderiam ser apresentadas no anfiteatro da Praça Tetê Salustino.

O Dia do Desafio é um projeto desenvolvido no mês de Janeiro, são $24 \mathrm{hrs}$ de esporte e lazer, onde oferece algumas atividades noturnas, sendo um diferencial importante. Esse projeto é aberto a toda população e o interessante é que atinge todas as faixas etárias, desde crianças até idosos.

É desenvolvido em diversos lugares da cidade, envolvendo a área urbana e rural. Como o foco da maioria dos projetos de lazer desenvolvidos pela Subcoordenadoria de Esporte e Lazer da SEMEC é o esporte, as atividades oferecidas no Dia do Desafio também são nesse âmbito.

As atividades são distribuídas em alguns bairros da cidade, aspecto interessante e que pode atingir diversos públicos, visto que a diversidade de atividades é considerável e cada bairro sedia algumas modalidades diferentes, vai de acordo com a disponibilidade e a configuração do espaço.

Dentre as modalidades oferecidas tem-se caminhada com maior número de participantes idosos; a trilha noturna de ciclismo; torneios de dominó, Le Parkour, futebol de mesa, xadrez e apresentação de artes marciais de Jiu Jitsu, Judô, Karatê e Capoeira, torneios de Handebol e Futsal feminino e masculino, de sinuca; de futsal mirim e vôlei de dupla feminino e masculino, de futebol society, corrida rústica, competição de skate; natação, torneios embaixadas e pescaria no Açude Currais Novos.

Pode-se perceber a diversidade de atividades e do público envolvido como também a abrangência do espaço utilizado para a realização do projeto. Mesmo com a falta de equipamentos públicos específicos para a prática do lazer no tocante do esporte, há uma 
apropriação dos espaços não específicos como a área da escola, que neste caso utilizaram alguns espaços como quadras e salas de aulas acessíveis no ambiente escolar.

Outra atividade desenvolvida pela SEMEC em conjunto com a SEMTHAS é o Passeio Ciclístico Figura 12 desenvolvido sempre no mês de novembro comemorando o aniversário da cidade.

Figura 12: Passeio Ciclístico

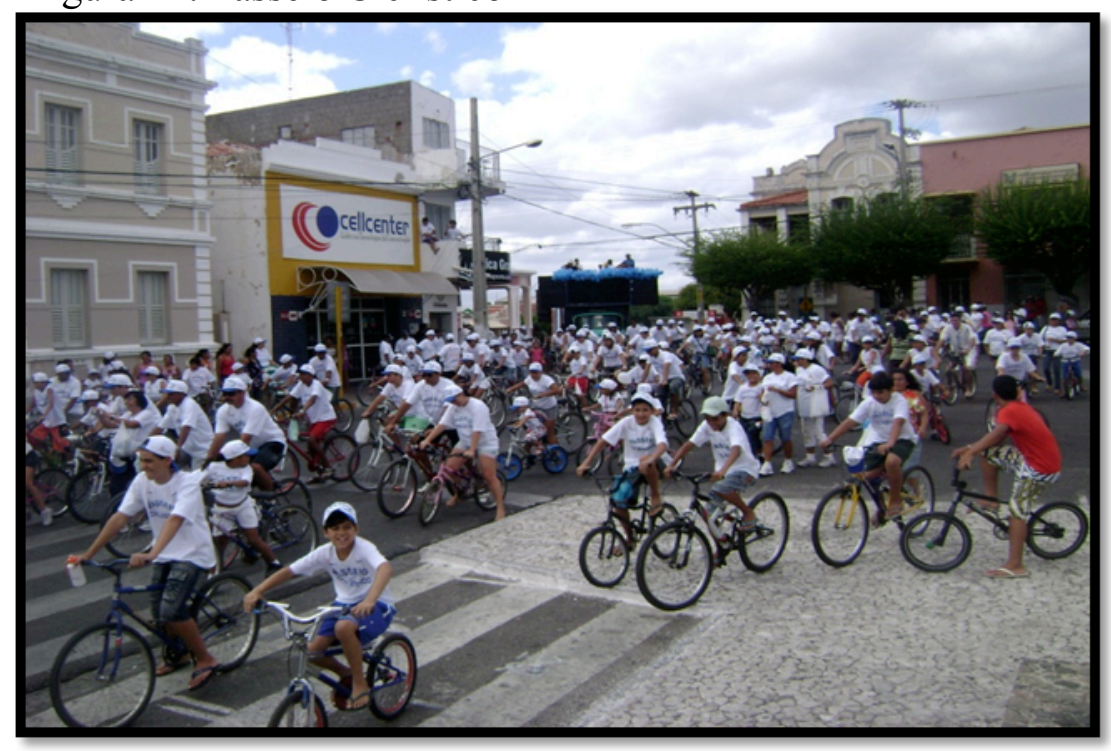

Fonte: Subcoordenadoria de Esporte e Lazer, 2012.

A promoção desses projetos é visto como um fator positivo para a prática do lazer na cidade, mas por outro lado, é direcionado basicamente para as pessoas que gostam da prática do esporte e estudantes, ficando sem opção as demais áreas de interesses e também todos estes citados são desenvolvidos durante o mês de Novembro à Janeiro, deixando os outros meses sem programação de lazer. Já que o foco principal das atividades de lazer promovidas pelo poder público é voltado para o esporte, poderia ser organizado um campeonato de Skate e esportes radicais específicos, em tempo distinto dos outros projetos que já desenvolvem.

Para o público idoso, há um projeto na Praça Cristo Rei de ginástica que oferece um acompanhamento técnico nas atividades físicas, com o objetivo de melhorar a qualidade 
de vida desses cidadãos. Esse projeto é desenvolvido por um funcionário da SEMEC com apoio da Prefeitura Municipal, gratuitamente para os idosos.

O espaço amplo que a Praça Cristo Rei dispõe deveria ser aproveitado para a implantação de uma Academia da Terceira Idade - ATI Figura 13, que atenderia as necessidades dos idosos que participam desse projeto de Ginástica que hoje é oferecido, melhorando a prática da atividade física e consequentemente a qualidade de vida dos frequentadores.

Figura 13: Exemplo de Academia da Terceira Idade

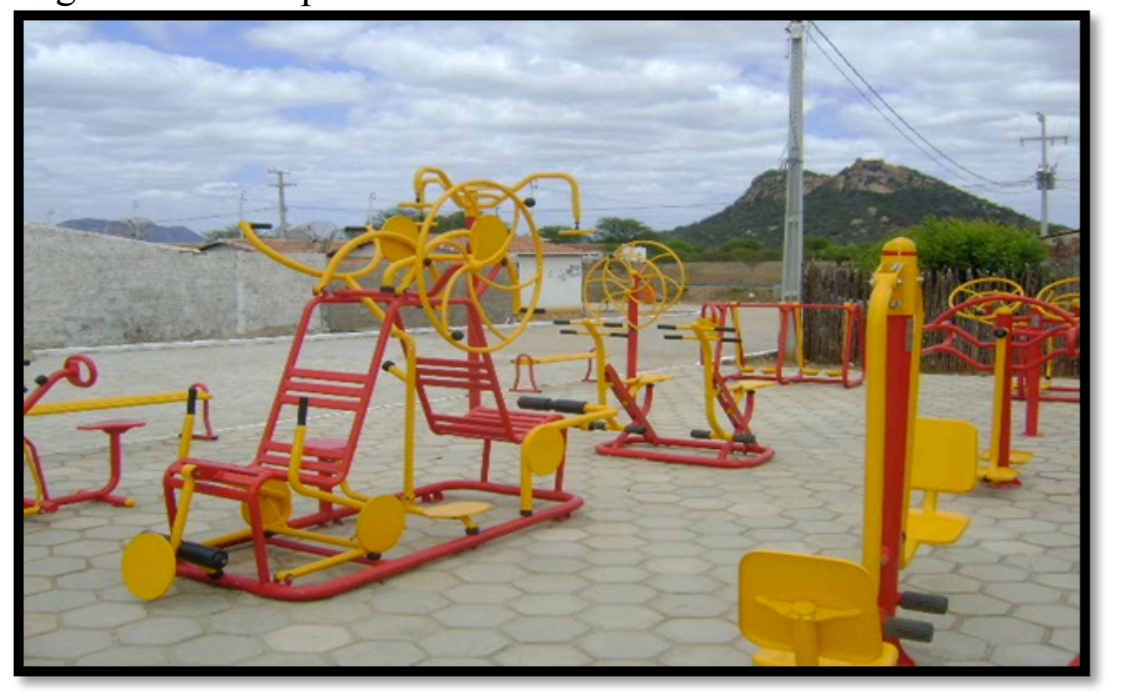

Fonte: Prefeitura Municipal de Messias Targino, 2012.

Uma outra forma de otimizar o espaço da Praça Cristo Rei é implantação de espaço para lazer infantil, como parques de madeiras em caixa de areia.

Outras atividades que proporcionam o lazer da comunidade, são os eventos sociais, como o Forronovos, o Carnaxelita que é um carnaval fora de época de cunho privado, mas oferecido em espaço público, as Festas de Padroeiras, o Cactus Moto Fest e o Forró do Pulsação, alguns são privados mas que são geralmente vistos como principal atividade de lazer dos munícipes, aspecto que pôde ser detectado durante as entrevistas com a população.

Diante da realidade da cidade de Currais Novos no âmbito de escolas, propõe-se a utilização do Programa Escola Aberta, desenvolvido pelo Ministério da Educação para 
promover lazer e cidadania à população local. Currais Novos possui um número elevado de escolas municipais e estaduais que podem sediar esse programa.

O Programa Escola Aberta utiliza do espaço das escolas para promover atividades educativas, esportivas, culturais, de lazer e formação inicial para trabalho. Diferente dos projetos que hoje são desenvolvidos pelo poder público local que delimita o público alvo na sua prática e são oferecidos apenas nas férias de fim de ano, o Escola Aberta não faz essa distinção. $\mathrm{O}$ ambiente escolar é aberto aos finais de semana com uma programação diferenciada e que atinge a todas as áreas de interesses, idade, sexo e classe social.

O poder público poderia intercalar o oferecimento das atividades já programadas com novos projetos, testando essa nova programação e observando satisfação do público.

O que deve ser melhorado para atender as questões do lazer e consequentemente ajudar no fomento da atividade turística é basicamente na oferta de equipamentos específicos de lazer, onde deve ser considerada a constituição daqueles que não existem hoje na cidade, não adianta investir em tipos de equipamentos que a cidade já dispõe para não haver uma desvalorização do espaço por parte da população.

Esse processo além de ajudar no fomento da atividade de lazer na cidade, também terá grande influência no embelezamento da mesma, melhoria na qualidade de vida da população e consequentemente será visto como uma oferta ou produto turístico desenvolvendo assim a atividade turística na localidade.

Observado essa realidade, foi pesquisado quais equipamentos de lazer, estes podendo ser público ou privado, a população gostaria que fossem oferecidos na cidade, entre as respostas estão:

- Cinema;

- Teatro;

- Museu; 
- Academias públicas nas praças;

- Shopping;

- Quadras de esportes mais equipadas;

- Balneários / Parque Aquático;

- Praças nos bairros periféricos;

- Centro de convivência;

- Ciclovia;

- Espaço específico para corrida;

- Praças com parques infantis;

Essa pesquisa foi realizada para poder identificar as necessidades da população frente aos equipamentos de lazer específicos para que o poder público utilize como base para os próximos investimentos na área do lazer como também na constituição de espaços que possam atrair uma demanda turística.

\section{CONSIDERAÇÕES FINAIS}

A necessidade do lazer é direito de todos e embora esteja regulamentada pela Constituição Federal de 1988, ainda existem algumas barreiras no que se refere à democratização do acesso ao lazer.

Desse modo, os objetivos da pesquisa foram alcançados, visto que a proposta permitiu realizar um estudo com a população curraisnovense visando conhecer o processo de apropriação dos espaços públicos para o lazer da comunidade.

A população geralmente utiliza dos espaços públicos de lazer para confraternização com familiares e amigos, prática de esportes e lanches nos quiosques e espetinhos espalhados em todos os bairros da cidade. 
Pode-se perceber também que a população possui algumas necessidades no que diz respeito à oferta de equipamentos específicos de lazer, sejam eles espaços públicos, semipúblicos ou privados.

Procurou-se avaliar os projetos e programas que são oferecidos atualmente pelo poder público à população, propondo atividades de melhoria e aperfeiçoamento dos mesmos, visando uma melhor socialização da população.

Com isso, chega-se a conclusão que os espaços públicos da cidade, são passíveis para a apropriação e uso da população para o lazer, mas há uma carência de atividades que possam atrair esse público periodicamente. Como também a falta de parcerias da iniciativa privada junto ao poder público nos investimento de novas áreas de lazer. E espera-se que este trabalho sirva como fonte de pesquisa para que o poder público possa trabalhar tais questões apresentadas durante a explanação dos resultados.

Assim, faz-se necessário uma atuação mais considerável do poder público nas ações que possam atender essas necessidades apresentadas durante este trabalho, incentivando e proporcionando melhores condições de desenvolvimento das atividades de lazer no município, buscando sempre a melhoria da qualidade de vida da população.

\section{REFERÊNCIAS}

BAHIA, Mirleide Chaar et. al. Os espaços e equipamentos de lazer das cidades: o caso de Belém / PA. In: FIGUEIREDO, S. L. (Org.). Turismo, lazer e planejamento urbano e regional. Belém: NAEA, 2008.

BLOG DECORARTE BRUM. Disponível em: http://decorartebrum.blogspot.com.br/2010_02_28_archive.html. Acesso em: 03 set. 2012.

BRASIL. Programa Escola Aberta. Educação. Disponível em: http://portal.mec.gov.br/index.php?option $=$ com content\&view $=$ article\&id $=16739 \&$ Itemid $=8$ 11 . Acesso em: 02 out. 2012.

Lei Orgânica Municipal. Câmara de Vereadores. Prefeitura Municipal de Currais Novos, 1990. 
BRUHNS, Heloísa T. (Org.). Introdução aos estudos do lazer. Campinas: Ed. UNICAMP, 1997.

CARVALHO, Leandro. Cidades: espaços públicos e privados. Escola Kids. Disponível em: http://www.escolakids.com/cidades-espacos-publicos-e-privados.htm . Acesso em: 08 set. 2012.

DENKER, Ada de Freitas Maneti. Métodos e técnicas de pesquisa em turismo. São Paulo: Futura, 2003.

DUMAZEDIER, Joffre. Lazer e Cultura Popular. São Paulo: Editora Perspectiva, 2004.

Sociologia empírica do lazer. São Paulo: Perspectiva: SESC, 2008.

FIGUEIREDO, Silvio Lima. Espaços públicos nas cidades: notas sobre o ordenamento, acessibilidade e turistificação. In: . (Org.). Turismo, lazer e planejamento urbano e regional. Belém: NAEA, 2008.

INSTITUTO BRASILEIRO DE GEOGRAFIA E ESTATÍSTICAS. IBGE Cidades. Disponível em: http://www.ibge.gov.br/cidadesat/topwindow.htm?1 . Acesso em: 03 out. 2012.

LOPES, Antônio Mendes. Os espaços públicos (de Lazer) na cidade: emergência de novas práticas e vocações territoriais. A página da educação. № 83. p. 20. Ano 8, 1999.Disponível em: http://www.apagina.pt/?aba=7\&cat=83\&doc=7773\&mid=2 Acesso em: 28 set. 2012.

MARCELLINO, Nelson Carvalho. Lazer e Cultura: algumas aproximações. In:

(Org.). Lazer e Cultura. Campinas: Editora Alínea, 2007.

Estudos do lazer: uma introdução. 4. ed. Campinas: Autores Associados, 2006.

PREFEITURA MUNICIPAL DE MESSIAS TARGINO. Academia da Terceira Idade. 2011. Disponível em: http://prefeiturademessiastargino.blogspot.com.br/2010/11/academiada-terceira-idade-sera.html . Acesso em: 28 out. 2012.

RIBEIRO, Zenilda Lopes. Praças e lazer: Dinâmica de uso e apropriação de espaços públicos em Sorriso - MT. 2008. Pluridoc. Disponível em:

http://www.pluridoc.com/Site/FrontOffice/default.aspx?Module=Files/FileDescription\&ID=1 833\&lang=pt Acesso em: 28 out. 2011.

ROTEIRO SERIDÓ. Disponível em: http://www.roteiroserido.com.br . Acesso em: 31 ago. 2012.

SIDY'S. Mapa da cidade de currais novos. Disponível em: < http://www.sidys.com.br/index.php?option $=$ com content\&view $=$ article\&id $=205 \&$ Itemid $=81$ > Acesso em: 08 out. 2012.

SILVA, Kelson de Oliveira. Espaços públicos, turismo e a privatização das áreas costeiras. In: Segunda residência, lazer e turismo. Maria Aparecida da Fonseca (Org.) Natal: EDUFRN, 2012. 
SUBCOORDENADORIA DE ESPORTE E LAZER. O esporte faz bem. Currais Novos, 2012. 8 slides, color. Acompanha texto.

TAVEIRA, Marcelo; GONÇALVES, Salete. Lazer e turismo: uma análise teórico-conceitual. In: Segunda residência, lazer e turismo. Maria Aparecida da Fonseca (Org.) Natal: EDUFRN, 2012.

VARELA, J. Largo Júnior Toscano. Idioma da bola. Disponível em: < http://www.idiomadabola.com/2012/02/currais-velhos-cidade-seridoense-que.html $>$ Acesso em: 31 out. 2012.

\section{Endereço das Autoras:}

Renata Laís Ferreira de Santana

Travessa Padre João Jeronimo167 - Centro

Santa Cruz - RN - CEP: 59200-000

Endereço Eletrônico: renatalais@bol.com.br

Josemery de Araújo Alves

Rua Major Lula 1226 - Paraiba

Caicó - RN - CEP:59300-000

Endereço Eletrônico: josemeryalves@hotmail.com 